\title{
Qaryah Thayyibah: Reposisi Eco-Literacy Melalui Pendidikan Berbasis Masyarakat
}

\author{
${ }^{1}$ Elina Lestariyanti, ${ }^{2}$ Mohammad Andi Hakim \\ 1Prodi pendidikan biologi, Fakultas Sains dan Teknologi, \\ Universitas Islam Negeri (UIN) Walisongo, Indonesia \\ 2IAIN Syekh Nurjati Cirebon, Indonesia
}

Email: 1elinalestari@walisongo.ac.id, 2andihakim@syekhnurjati.ac.id

\section{Tersedia Online di}

http://www.jurnal.unublitar.ac.id/ index.php/briliant

\section{Sejarah Artikel \\ Diterima pada 14 Juni 2020 \\ Disetujui pada 29 Agustus 2020 \\ Dipublikasikan pada 31 Agustus 2020 Hal. 573-583}

\begin{tabular}{l}
\hline Kata Kunci: \\
\hline Community; Education, \\
Biology; Learning; Qaryah \\
Thayyibah \\
\hline DOI: \\
\hline http://dx.doi.org/10.28926/briliant \\
.v3i4.483
\end{tabular}

\begin{abstract}
Abstrak: Eco-literacy menunjukan kesadaran tentang pentingnya lingkungan hidup. Kesadaran betapa pentingnya menjaga dan merawat bumi, ekosistem, alam sebagai tempat tinggal dan berkembangnya kehidupan. Pendidikan merupakan piranti paling ideal dalam menumbuhkan kesadaran tersebut, salah satunya melalui ilmu biologi. Bidang ilmu yang begitu dekat dengan fenomena keseharian manusia dan relasinya dengan lingkungan hidup. Namun, proses pembelajarannya sejauh ini hanya dibebankan dan terbatas pada institusi formal. Masyarakat sebagai bagian dari sistem sosial anak tidak saling terhubung dengan sekolah. Praktik pembelajaran biologi di sekolah menjadi terbatas pada konseptual-hafalan bukan kontekstualpenerapan. Sekolah Alternatif Qaryah Thayyibah adalah sekolah yang menerapkan sistem pendidikan berbasis pada masyarakat (Community Based Education). Penelitian ini menggunakan metode kualitatif deskriptif. Subjek penelitian adalah kepala
\end{abstract} sekolah sekaligus pendiri sekolah, pendamping belajar, warga belajar, orang tua dan masyarakat desa setempat. Data dikumpulkan melalui wawancara, observasi dan studi dokumentasi. Hasil penelitian menunjukkan bahwa implementasi pendidikan berbasis masyarakat di sekolah alternatif Qaryah Thayyibah diwujudkan melalui akses, kontrol, partisipasi aktif dan keberterimaan manfaat masyarakat Desa Kalibening. Proses mempelajari ilmu biologi dijalankan melalui pembelajaran aktif, kontekstual dan aplikatif yang berbasis kebutuhan anak melalui optimalisasi sumber daya desa dan potensi masyarakat desa.

\section{PENDAHULUAN}

Pendidikan adalah sarana pembentuk karakter dan pengasah potensi anak (potensial human) untuk kelak siap hidup bersama masyarakat. Sebagian besar penyelenggaraan pendidikan sayangnya gagal menyadari manfaat dan pentingnya pelibatan masyarakat dalam proses anak memperoleh pengetahuan (Melaville, et al., 2006). Lingkaran sistem sosial kehidupan anak seperti masyarakat, keluarga dan lingkungan tempat tinggal justru tidak saling terhubung (disengage) dengan sekolah. Penyelenggaraan pendidikan menjadi hanya tanggungjawab institusi pendidikan, sedangkan pihak-pihak di luar institusi formal pendidikan tidak dilibatkan untuk berpartisipasi menyiapkan situasi dan kondisi yang edukatif bagi anak (Baharuddin \& Makin, 2007). 
Pengasingan pengetahuan dengan kehidupan sehari-hari dapat berdampak pada tumpulnya nalar kritis anak dalam membaca realitas sosial. Anak yang mengalami alienasi pengetahuan dengan realitas sosial akan cenderung menjadi adaptor terhadap permasalahan di lingkungan sekitarnya daripada menjadi subjek aktif yang melakukan perubahan. Watak pasif dan adaptor ini selanjutnya dapat menggiring anak pada sikap dan amaliyah yang tidak acuh bahkan egois terhadap makhluk dan lingkungan. Konsep pendidikan berbasis masyarakat yang mengaitkan pengetahuan anak di sekolah dengan lingkungan sehari-hari dan masyarakat menjadi relevan untuk menjawab tantangan permasalahan pembelajaran yang terpisah dengan masyarakat.

Sejak Zlotkowski (1995) menyerukan integrasi kurikulum dengan pembelajaran layanan masyarakat (service learning community) nampak adanya peningkatan dukungan dan adopsi sistem tersebut dalam pendidikan (Bauer et al., 2015; Perrotti, 2019). Dinyatakan dalam berbagai penelitian bahwa pelibatan masyarakat dalam proses pembelajaran mampu membentuk karakter positif bagi anak diantaranya rasa ingin tahu yang tinggi, terbentuk tali-hubung antara siswa dan sekolah serta komunitas (Ferguson, 2006), kemampuan transfer pengetahuan di kelas dengan konteks di lapangan (Wickersham, et al., 2016), partisipatif (Eyler, et al., 2001), reflektif, serta anak memiliki cara pandang yang melihat diri sendiri dan orang lain secara sejajar dan menghargai (equal prespective) (Bauer et al., 2015). Galbraith (1995) menegaskan bahwa pendidikan berbasis masyarakat bahkan mampu membentuk karakter pembelajar sepanjang hayat (lifelong learner) pada anak sekaligus menciptakan masyarakat pembelajar (learning society).

Semangat penyelenggaraan pendidikan berbasis masyarakat di Indonesia sesungguhnya telah dicantumkan dalam Undang-Undang Sistem Pendidikan Nasional Nomor 20 Tahun 2003 yaitu penyelenggaraan pendidikan yang didasarkan pada kekhasan agama, sosial, budaya, aspirasi, dan potensi masyarakat sebagai perwujudan pendidikan dari, oleh, dan untuk masyarakat. Pelibatan masyarakat dalam penyelenggaraan pendidikan juga dijelaskan bahwa masyarakat memiliki kewajiban untuk memberikan dukungan sumberdaya dalam penyelenggaraan pendidikan serta memiliki tanggung jawab terhadap keberlangsungan penyelenggaraan pendidikan (UU Sisdiknas, 2003). Makna pendidikan berbasis masyarakat ini sesuai dengan penjabaran Galbraith (1995) bahwa penyelenggaraan pendidikan berbasis masyarakat adalah upaya meningkatkan partisipasi demokratis sehingga pendidikan dapat mengarahkan pengetahuan, sikap dan keterampilan individu untuk menjadi pribadi yang lebih kompeten dalam menjalani hidup di masyarakat.

Pada sisi yang lain, Eco Literacy menjadi penting sebagai upaya membangun kesadaran tentang pentingnya menjaga lingkungan hidup. Keraf (2014) mendeskripsikannya sebagai melek ekologis, dimana manusia telah mencapai kesadaran yang sangat tinggi tentang pentingnya menjaga lingkungan. Mc Beth \& Volk (2010) memberikan narasinya pentingngya membangun kesadaran literasi adalah melalui pendidikan lingkungan. Hal ini menjadi kunci dalam menyelesaikan masalah-masalah lingkungan, karena fokus bukan pada tindakan kerusakan yang dilakukan, melainkan menyadarkan manusianya.

Mc Beth \& Volk (2010) menjelaskan pula tentang bagian-bagian penting dalam literasi ekologis, antara lain Pengetahuan Ekologis, Sikap Ekologis, Keterampilan Kognitif, dan Perilaku Lingkungan. Keempat hal tersebut menjadi 
indikator seserang memiliki kesadaran dan wawasan literasi lingkungan. Praktiknya, untuk menjadi literat ekologis, manusia harus memiliki pengetahuan yang baik terkait dengan lingkungan, komitmen, sensitivitas dan sikap terhadap lingkungan. Selain itu, kemapuan identifikasi isu, analisis isu dan rencana aksi juga menjadi penting untuk mewujudkan kesdaran tersebut menjadi aksi nyata menjaga dan merawat lingkungan. Puncaknya, kita mampu menjadi pribadi dengan komitmen aktual untuk melestarikan alam.

Upaya paling efektif dalam membangun kesadaran lingkungan adalah melalui pendidikan. Pendidikan menjadi senjata paling ampuh dalam membentuk pribadi yang cinta lingkungan, salah satunya melalui pendidikan biologi. Biologi adalah bidang ilmu yang sangat dekat dengan masyarakat dan perilaku keseharianya terhadap lingkungan. Kepadatan penduduk, perubahan iklim, pelestarian lingkungan, pembaruan energi, penyakit-penyakit baru, peningkatan produksi pangan adalah sebagian dari masalah kehidupan di masyarakat yang berkaitan erat dengan prinsip, hukum dan teori biologi. Fakta ini memperkuat pentingnya ilmu biologi dipelajari secara kontekstual dan aplikatif karena biologi memiliki karakteristik terus berkembang dan berpotensi menemukan solusi kebutuhan masyarakat (National Research Council, 2009). Nwosu (2005) juga menegaskan bahwa ilmu biologi dapat menjadi platform untuk membangun kemampuan siswa menerapkan konsep-konsep dan prinsip-prinsip sains dalam memecahkan masalah kehidupan sehari-hari. Oleh karena itu, kerjasama antara sekolah dengan masyarakat sepatutnya diperkuat agar jurang (gap) antara pengetahuan di sekolah dengan komunitas atau masyarakat dapat saling terhubung (Ma'arif et al., 2012; Melaville et al., 2006).

Salah satu sekolah yang menerapkan konsep pendidikan berbasis masyarakat adalah Sekolah Alternatif Qaryah Thayyibah di Desa Kalibening Salatiga. Sekolah tersebut melaksanakan proses pendirian, perencanaan, pelaksanaan, pengelolaan, pengawasan, dan evaluasi pendidikan bersama dengan masyarakat. Konsep pendidikan berbasis masyarakat yang diterapkan di sekolah alternatif Qaryah Thayyibah menjadi landasan penulisan best practice implementasi konsep pendidikan berbasis masyarakat (community based education) pada pembelajaran biologi.

\section{METODE}

Penelitian menggunakan pendekatan kualitatif deskriptif. Penelitian dilakukan di Sekolah Alternatif Qaryah Thayyibah Desa Kalibening Kecamatan Tingkir Kota Salatiga Jawa Tengah. Pengambilan data dilakukan dengan teknik observasi partisipatif, wawancara mendalam dan studi dokumen. Partisipan penelitian yaitu kepala sekolah sekaligus pendiri sekolah, pendamping belajar, siswa, orang tua siswa dan masyarakat desa Kalibening. Keabsahan data penelitian diuji menggunakan triangulasi teknik dan triangulasi sumber.

\section{HASIL}

Inisiasi penyelenggaraan pendidikan oleh Qaryah Thayyibah berawal dari keterbatasan ekonomi dan tantangan geografi kelompok masyarakat miskin di Desa Kalibening. Mahalnya Biaya pendidikan serta lokasi sekolah yang jauh menjadi latar hambatan masyarakat Desa Kalibening untuk memenuhi kebutuhan pendidikan dasar bagi anak mereka. Latar sosiologis dan geografis tersebut menjadi 
pendorong masyarakat desa untuk bersepakat mendirikan dan menyelenggarakan pendidikan yang ramah dan murah bagi masyarakat. Prinsip pendidikan dari, oleh dan untuk masyarakat dipilih sebagai prinsip pendidikan Qaryah Thayyibah yaitu prinsip yang memberikan keluasan akses, partisipasi, kontrol dan manfaat pendidikan bagi masyarakat. Prinsip-prinsip tersebut selanjutnya dituangkan ke dalam visi, misi dan tujuan pendidikan Sekolah Alternatif Qaryah Thayyibah antara lain: Pertama, Pendidikan yang membebaskan yaitu pelaksanaan pembelajaran tidak membendung kreativitas dan jiwa kritis anak. Kedua, Keberpihakan pada seluruh warga belajar yaitu pendidikan dan pengetahuan adalah hak setiap orang sehingga tidak ada diskriminasi dalam pendidikan yang mengakibatkan orang lain tidak mampu mengakses pendidikan layak. Ketiga, Partisipatif dan keterlibatan antara pengelola, orang tua, anak dan masyarakat dalam merancang sistem pendidikan.

Keempat, Kurikulum berbasis kebutuhan warga belajar dan masyarakat sekitar sebagai bagian dari usaha menjawab kebutuhan pengelolaan dan penguatan sumberdaya lokal yang tersedia untuk menjaga kelestarian lingkungan. Kelima, metode pembelajaran kerja sama yaitu metode pembelajaran yang dibangun selalu didasarkan pada proses kerjasama antara pendamping belajar dan warga belajar yang sama-sama berproses dalam belajar. Keenam, evaluasi berpusat pada subjek belajar, dan Ketujuh percaya diri pengakuan atas keberhasilan bergantung pada subjek pembelajar sendiri bukan dari ijazah atau pengakuan dari pihak lain.

Prinsip pendidikan yang diselenggarakan oleh Qaryah Thayyibah sejalan dengan penjabaran karakteristik pendidikan berbasis masyarakat menurut McGivney (1999) dan Komisi Universitas di UK (2011) yaitu pendidikan diselenggarakan di lokasi yang dekat dengan masyarakat dan tempat tinggal anak. Selain itu, pendidikan ditawarkan dengan biaya murah sehingga mudah diakses bagi kelompok masyarakat ekonomi rendah. Karakteristik yang juga melekat pada pendidikan berbasis masyarakat adalah masyarakat didorong untuk berpartisipasi dan terlibat dalam penyelenggaraan pendidikan di sekolah. Ciri pendidikan berbasis masyarakat yang dijabarkan oleh Galbraith (1955) juga tercermin dari latar belakang pendirian Qaryah Thayyibah berupa kemampuan masyarakat mendayagunakan kapasitas dan sumberdayanya untuk memecahkan permasalahan yang dihadapi (self help). Kemampuan masyarakat Desa Kalibening dalam menyelesaikan masalah yang dihadapi semakin menegaskan bahwa secara fitrah masyarakat memiliki potensi untuk mengatasi masalah sendiri (Rosyada, 2007). Masyarakat melalui fitrah kemanusiaannya dapat menjadi penolong bagi diri sendiri (self help) dan bahkan dapat menjadi penyedia layanan pendidikan terbaik di komunitasnya (Galbraith, 1995).

\section{PEMBAHASAN}

\section{Praktik Pendidikan Berbasis Masyarakat di Qaryah Thayyibah}

Prinsip-prinsip pendidikan berbasis masyarakat di Qaryah Thayyibah yang dituangkan dalam visi, misi dan tujuan sekolah menjadi landasan dalam praktik pembelajaran anak di sekolah. Dimulai dari proses perencanaan, pelaksanaan hingga evaluasi pembelajaran. 


\section{Kurikulum Berbasis Kebutuhan}

Proses perencanaan pembelajaran di Qaryah Thayyibah tidak secara tertulis berbentuk silabus mengikuti kurikulum nasional. Sejalan dengan semangat visi misi sekolah yang mengacu pada model pendidikan membebaskan dan berpihak pada warga belajar, kurikulum sebagai acuan proses belajar di Qaryah Thayyibah dirumuskan oleh anak berdasarkan kebutuhan dan kompetensi anak. Kurikulum tersebut dinamakan KBK atau Kurikulum Berbasis Kebutuhan.

Rencana belajar (lesson planning) disusun secara berkala. Setiap anak merumuskan dan menyusun rencana belajar mereka didampingi oleh guru atau pendamping belajar. Setiap anak menyusun rincian topik, materi dan kegiatan belajar setiap hari untuk satu minggu. Mereka diberi kebebasan atau keleluasaan menentukan konten atau topik materi yang akan dipelajari. Strategi perumusan rencana pembelajaran bersama antara anak dan pendamping belajar ini diyakini oleh pendiri sekolah dapat menanamkan karakter anak yang kreatif, percaya diri, mandiri, bekerja keras dan bertanggungjawab. Sebagaimana hasil wawancara dengan anak bahwa kebebasan berpendapat dan berkreasi di Qaryah Thayyibah dapat menumbuhkembangkan kreativitas yang diiringi rasa tanggungjawab.

\section{Desa dan Masyarakat sebagai Laboratorium}

Pelibatan secara langsung masyarakat dan desa tempat tinggal anak dalam memperoleh pengetahuan adalah salah satu prinsip pembelajaran yang dijalankan oleh Qaryah Thayyibah. Konteks kehidupan sosial masyarakat desa, kekhasan sumber daya alam, kearifan lokal dan potensi-potensi di desa menjadi laboratorium besar bagi anak untuk belajar.

Upaya sekolah mendekatkan anak dengan masyarakat sekitar diantaranya dengan mendatangi masyarakat desa dengan beragam profesi (petani, peternak, dokter, guru, wirausahawan, kyai dan seterusnya) untuk berbagi pengetahuan. Kegiatan belajar dilakukan dengan mendatangkan masyarakat dengan beragam profesi tersebut ke sekolah atau anak secara langsung datang ke tempat tinggal atau tempat mereka bekerja. Pendamping belajar menyakini, proses belajar yang membiasakan anak melakukan interaksi aktif dengan masyarakat dapat menumbuhkan sikap toleran, inklusif, egaliter dan komunikatif.

Eksplorasi sumber daya desa seperti sawah, kebun, sumber mata air desa, ragam flora dan fauna lokal adalah cara lain pihak sekolah mendialogkan anak dengan alam sekitar. Desa dengan segala potensinya menjadi laboratorium anak untuk memperoleh pengetahuan. Proses pembelajaran ini melatih anak untuk peka atau sensitif dan peduli. Disampaikan oleh pendiri Qaryah Thayyibah bahwa bahwa kurikulum nasional menjadikan anak pintar namun kurang arif karena tidak mengenal lingkungan sekitar, potensi dan kondisi desanya. Tidak ada pelibatan anak untuk ikut memikirkan perbaikan desa, melakukan konservasi atau pelestarian sumber daya di desanya. Anak tidak dibiasakan berhadapan dengan kompleksitas permasalahan di masyarakat, anak tergiring menjadi pribadi yang tidak acuh. Atas landasan pemikiran tersebut, proses pembelajaran di Qaryah Thayyibah mengarahkan pada interaksi dan komunikasi secara langsung dan intens dengan masyarakat dan desa tempat tinggal anak. 


\section{Penjagaan terhadap tradisi dan kearifan Lokal}

Selain fokus pada upaya untuk membangun kesadaran melalui aktivitas pembelajaran, Qariyah Tayibah juga memberi perhatian pada tradisi dan kearifan lokal masyarakat setempat. Wawasan ekolinguistik juga diaplikasikan dalam proses mewujudkan kesadaran menjaga lingkungan. Siswa bersama masyarakat memahami bahwa ekosistem sebagai bagian dari kehidupan manusia dan bahasa sebagai alat komunikasi yang digunakan dalam aktivitas sehari-hari dapat sejalan dan saling memberi manfaat.

Gayoni (2010) menguraikan bahwa lingkungan fisik dan kondisi sosialnya berimplikasi pada penggunaan bahasa masyarakatnya secara psikologis. Praktiknya, ekolinguistik menganalisis bahasa tuturan maupun literal yang berkaitan dengan lingkungan. Pembelajaran di Sekolah mengajarkan tentang bagaimana kata dalam bahasa merujuk pada objek-objek alam dan lingkungan disekitar rumah dan sekolah. Hal ini yang kemudian terjadi dalam aktivitas pendidikan di sekolah tersebut. Upaya melestarikan ungkapan-ungkapan sosio kultural yang berkaitan dengan ilmu biologi dan lingkungan menjadi perhatian. Istilah-istilah yang berkaitan dengan objek, upacara adat, konsep ruang dan tanah, hingga pengelolaan sumber daya alam.

\section{Biologi dan Penerapan Pendidikan Berbasis Masyarakat}

Qaryah Thayyibah menerapkan integrasi keilmuan dalam konsep pembelajarannya. Tiap bidang ilmu tidak dipelajari dalam bentuk mata pelajaran atau bidang kajian yang terpisah, namun secara utuh dipelajari berdasarkan topik atau konten sesuai rencana belajar yang disusun anak.

Ilmu biologi dipelajari melalui pembelajaran kontekstual dan berkaidah lokalitas. Proses mempelajari ilmu biologi dengan cara mencari pengalaman dan melakukan aktivitas bersama masyarakat atau komunitas setempat. Kekhasan proses belajar di Qaryah Thayyibah yaitu anak melakukan observasi di lingkungan desa dan wawancara ke masyarakat (metode saintifik). Proses perolehan pengalaman dan pengetahuan selanjutnya ditulis dan didiskusikan anak di kelas. Hasil diskusi diarahkan oleh pendamping belajar untuk disusun ide atau gagasan. Ide atau gagasan tersebut selanjutnya direalisasikan melalui kerja praktik, pembuatan karya atau projek kelas. Ilustrasi proses pembelajaran biologi dapat dilihat pada skema pada gambar 1 .

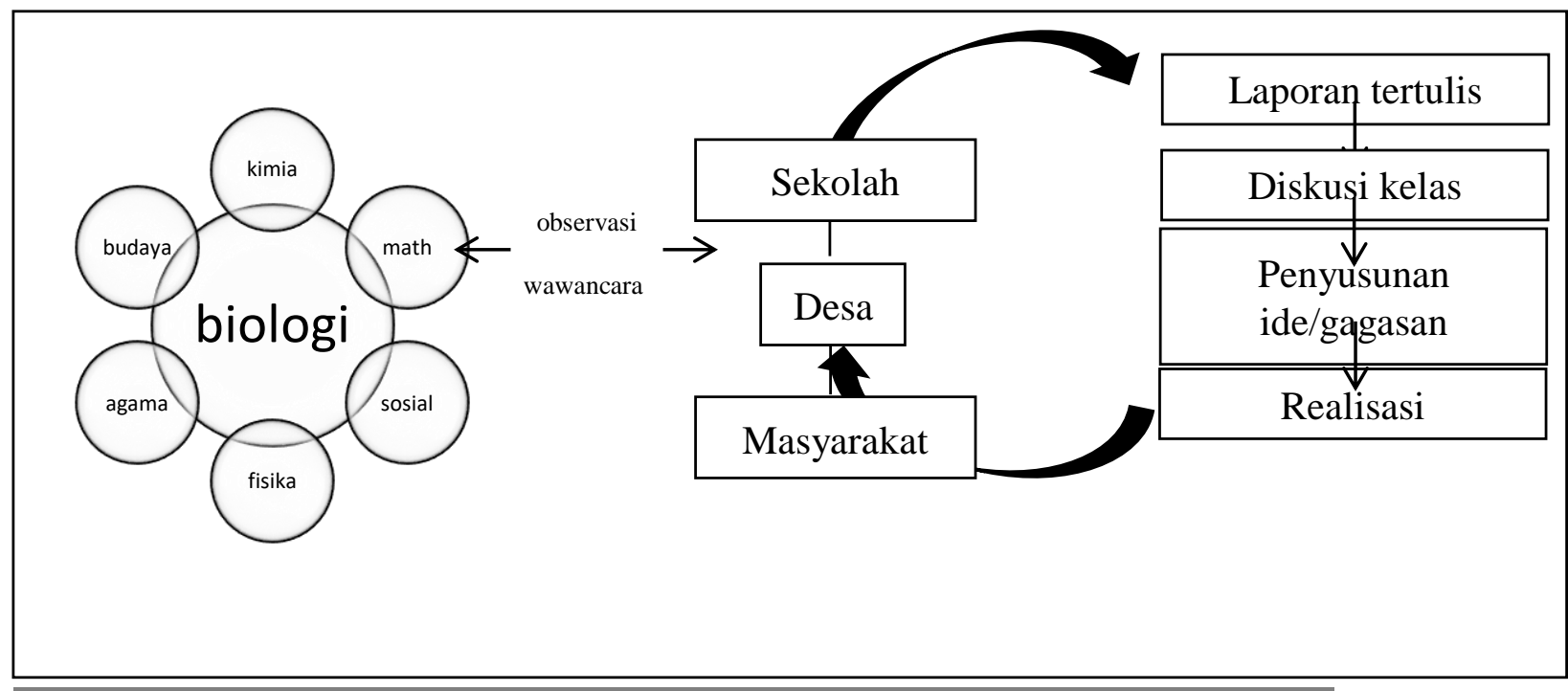

578 BRILIANT: Jurnal Riset dan Konseptual

Volume 5 Nomor 3, Agustus 2020 
Mempelajari ilmu biologi menjadi jauh dari kesan menghafal dan menghimpun konsep, prinsip atau teori biologi. Proses belajar menjadi aktivitas yang menyenangkan, kontekstual serta relevan dengan kehidupan nyata anak. Proses belajar yang dilaksanakan oleh Qaryah Thayyibah juga menunjukkan idealitas atau hakikat dari belajar sains yakni adanya pengalaman dan aktivitas ( $a$ set of methods/processes science) yang didesain untuk memahami fakta, prinsip dan konsep biologi (body of knowledge) sehingga dapat memunculkan sikap ilmiah (the value of science) seperti rasa ingin tahu, jujur, teliti, dan tanggung-jawab.

Hasil wawancara, observasi dan studi dokumen menunjukkan adanya kesamaan cakupan pokok bahasan pada kurikulum nasional dengan pelaksanakan pembelajaran biologi di Qaryah Thayyibah. Tabel 1. Menjabarkan hasil analisis ruang lingkup kajian biologi integratif-kontekstual di Qaryah Thayyibah dengan kompetensi dasar (KD) mata pelajaran biologi dalam kurikulum nasional.

Tabel 1. Analisis kompetensi dasar (KD) mata pelajaran biologi pada kurikulum nasional dengan proses pembelajaran biologi di Qaryah Thayyibah

\section{N Mata Pelajaran \\ O Biologi dalam Kurikulum Nasional}

1. Keanekaragaman hayati

2. Virus dan peranannya dalam kehidupan

3. Mikroorganisme bakteri dan peranannya dalam kehidupan

4. Jamur dan peranannya dalam kehidupan

5. Ekologi dan aliran energi

\section{Ruang Lingkup Materi dan Kegiatan Kajian Biologi di Qaryah Thayyibah}

(1) Keanekaragaman tumbuhan di desa

(2) Keanekaragaman hewan di desa

(3) Ragam manfaat tanaman obat di desa

(4) Observasi hewan dan tumbuhan di sawah, sumber mata air dan lingkungan sekitar desa

(5) siklus hidup dan proses pelestarian tanaman di desa

(6) Menyusun taksonomi tumbuhan di desa

(7) Menggali potensi dan permasalahan tanaman di desa melalui wawancara dengan petani

(1) Karakteristik, struktur tubuh dan daur hidup virus

(2) Proses daur hidup virus

(3) Penyakit-penyakit baru yang diakibatkan oleh virus (HIV/AIDS, flu burung, ebola, mers, zika dan seterusnya)

(4) Dampak, penyebaran dan penanganan penyakit akibat virus

(1) Karakteristik, struktur tubuh dan daur hidup bakteri

(2) Peranan bakteri bagi manusia

(3) Pembuatan pupuk organik dari sampah organic di desa

(4) Pembuatan bio-urine dari urin sapi milik peternak di desa

(5) Pembuatan Biogas dari kotoran ternak di desa

(1) Karakteristik, struktur tubuh dan daur hidup jamur

(2) Pelatihan budidaya jamur

(3) Praktik budidaya jamur bersama komunitas masyarakat

(1) Observasi ekosistem desa dan peranannya bagi kehidupan desa

(2) Pembuatan briket dari sampah daun sebagai solusi harga bahan bakar di desa yang mahal 
6. Perubahan lingkungan (1) Lingkungan dan permasalahan lingkungan di desa dan daur ulang limbah (sampah plastik, kerusakan ekosistem sumber mata air sinjoyo, penggunaan pestisida dan pupuk kimia pada tanaman yang merusak lingkungan, dan lain-lain

(2) Dampak ketidakseimbangan lingkungan terhadap kehidupan manusia dari segi ekonomi, kesehatan dan kesejahteraan manusia

(3) Pendirian bank sampah desa

(4) Daur ulang sampah plastik menjadi barang-barang kerajinan tangan

(5) Pembuatan sumur resapan dan biopori bersama komunitas di desa

(6) Pembuatan film mengenai penggunaan plastik

(7) Pembuatan artikel/opini di majalah dinding sekolah dan media cetak tentang penggunaan sampah plastik dan kebijakan pemerintah tentang penggunaan plastik berbayar

(8) Penulisan buku tentang kerusakan lingkungan dan upaya pelestarian

7. Jaringan pada manusia (1) Konsep jaringan dan macam jaringan pada manusia

(2) Penyakit pada jaringan manusia

8. Struktur dan sistem (1) Struktur biologis tubuh manusia (organ manusia, anggota biologis tubuh manusia gerak tubuh, otak manusia, dan sistem pada tubuh manusia)

(2) Penyakit pada manusia akibat pola hidup tidak sehat

(3) Upaya menjaga kesehatan tubuh

(4) Pemberlakukan gaya hidup sehat di peraturan sekolah

9. Materi Genetik

(1) Materi genetik sebagai kesaksian generasi ke generasi (mesin waktu)

(2) Pewarisan sifat pada makhluk hidup

(3) Pengamatan keanekaragaman pewarisan sifat pada makhluk hidup melalui pengamatan struktur wajah dan struktur tubuh di lingkungan keluarga dan lingkungan sekitar

10 Evolusi (1) Konsep evolusi

(2) Dampak Evolusi pada kehidupan

\section{Implikasi}

Proses pengkajian biologi dengan menerapkan konsep pendidikan berbasis masyarakat dapat menjawab tantangan dinamisitas peradaban. Proses belajar yang melibatkan anak dalam pemecahan permasalahan sosial, ekonomi dan budaya mengantarkan anak menjadi pribadi yang percaya diri dalam mengagendakan perubahan-perubahan di lingkungan tempat tinggalnya. Kesadaran masyarakat untuk terlibat menyiapkan situasi dan kondisi yang edukatif dan kondusif bagi anak serta merta menghindarkan anak dari keretakan kepribadian (split personality) akibat kontradiksi materi yang diterima di sekolah dengan fenomena ketimpangan di masyarakat (Baharuddin \& Makin: 2007). Hal senada disampaikan oleh anak yang belajar di Qaryah Thayyibah. Dinyatakan bahwa proses belajar yang 
mendialogkan pengetahuan di sekolah dengan realita kehidupan masyarakat memunculkan kedekatan dan rasa kepemilikan (sense of belong) terhadap lingkungan dan komunitasnya.

Aktivitas belajar di Qaryah Thayyibah juga tidak dibatasi golongan umur, tempat dan waktu tertentu. Anak dan semua lapisan masyarakat Desa Kalibening secara bersama-sama saling belajar. Proses belajar menjadi tujuan bersama untuk memajukan dan menyejahterakan kehidupan masyarakat. Masyarakat yang terus menerus belajar secara bertahap akan memperoleh daya, kekuatan dan kemampuan yang bermanfaat dalam proses pengambilan keputusan secara mandiri. Masyarakat yang terus belajar dinyatakan oleh Galbraith (1995) dapat menciptakan pendidikan sepanjang hayat (long life education) dan mengarah pada masyarakat yang berdaya (advance society).

Hal yang sama dinyatakan oleh Pendiri Qaryah Thayyibah bahwa komunitas yang senantiasa belajar pasti akan berkontribusi pada terbentuknya masyarakat pembelajar. Masyarakat pembelajar akan membentuk masyarakat yang unggul dan berdaya. Masyarakat yang mandiri dan berdaya dapat menjadi bagian dari usaha memerangi kesenjangan sosial seperti kemiskinan, pengangguran, ketimpangan sosial dan pemerataan pendidikan. Masyarakat yang berdaya tersebut dapat menepis pandangan sempit sebagian kelompok yang menyatakan bahwa pembangunan di daerah pedesaan hanya mungkin dilaksanakan jika ada intervensi dari pihak luar dikarenakan sikap fatalisme dan ketergantungan yang melekat pada sikap masyarakat (Combs \& Ahmed, 1985).

\section{KESIMPULAN}

Masalah lingkungan menjadi urgen untuk diatasi, mengingat hal ini memunculkan kerusakan dan pemanfaatan lingkungan yang tidak baik. Salah satu upaya preventif untuk mengatasi ketimpangan tersebut adalah melalui pembelajaran yang menumbuhkan kesadaran akan pentingnya lingkungan hidup. Eco-literacy yang menggambarkan kesadaran tentang pentingnya lingkungan hidup. Sebuah capaian di mana seseorang sudah sangat menyadari betapa pentingnya lingkungan hidup, pentingnya menjaga dan merawat bumi, ekosistem, alam sebagai tempat tinggal dan berkembangnya kehidupan. Upaya untuk mewujudkan hal tersebut adalah melalui pendidikan biologi berbasis masyarakat di sekolah alternatif Qaryah Thayyibah. Melalui akses, kontrol, partisipasi aktif dan keberterimaan manfaat masyarakat, proses mempelajari ilmu biologi dijalankan melalui pembelajaran aktif, kontekstual dan aplikatif yang berbasis kebutuhan anak melalui optimalisasi sumber daya desa dan potensi masyarakat desa. Sehingga masyarakat begitu menyatu sebagai bagian yang tidak terpisahkan dalam pendidikan.

\section{SARAN}

Penyelenggaraan pendidikan seharusnya tidak memisahkan sekolah dengan masyarakat. Pelibatan masyarakat sebagai bagian penting dalam mewujudkan keberhasilan proses pendidikan harus dihadirkan perannya. Pendidikan berbasis masyarakat tercermin dalam visi, misi dan tujuan Sekolah Alternatif Qaryah Thayyibah. Konsep pendidikan berbasis masyarakat yang diterapkan menjadi model ideal yang melibatkan interaksi masyarakat desa tempat tinggal anak. Proses mempelajari ilmu biologi menjadi dinamis, kontekstual dan aplikatif. Melalui 
kerjasama penyelenggaraan pendidikan dengan pihak di luar institusi formal sekolah yaitu masyarakat, anak menjadi subjek aktif yang ikut terlibat dalam proses pemecahan masalah di desanya.

\section{DAFTAR RUJUKAN}

Bahruddin, A. 2007. Pendidikan Alternatif Qaryah Thayyibah. Yogyakarta: LKIS. Baharuddin \& Makin, M. 2007. Pendidikan Humanistik (Konsep, Teori dan Aplikasi Praksis dalam Dunia Pendidikan). Yogjakarta: Ar-Ruzz Media.

Bauer, T., Kniffin, L. E., \& Priest, K. L. (2015). The Future of Service-Learning and Community Engagement: Asset-Based Approaches and Student Learning in First-Year Courses Service-Learning in a First-Year Course. Michigan Journal of Community Service Learning, 22(1), 89-92. Retrieved from https://files.eric.ed.gov/fulltext/EJ1137421.pdf

Combs, P. H. \& Ahmed, M. 1985. Memerangi Kemiskinan di Pedesaan Melalui Pendidikan Non-Formal. Jakarta: Rajawali.

Eyler, J. S., Giles, D. E., Stenson, C. M., \& Gray, C. J. (2001). At A Glance: What We Know About The Effects of Service Learning on Student, Faculty, Institutions, and Communities, 1993-2000: Third Edition. Nashville, TN: Vanderbilt University Press.

Ferguson, A. (2006). Making the Case for Service-Learning in First-Year Programs. The Vermont Connection, 27.

Galbraith, M. W. (1995). Community-Based Organizations And The Delivery Of Lifelong Learning Opportunities.

Keraf, A. S. (2014). Filsafat lingkungan hidup, alam sebagai sebuah sistem kehidupan. Yogyakarta: Kanisius

Ma'arif, S., Kholiq, A., \& Elizabeth, M.Z. 2012. School Culture di Madrasah dan Sekolah. Semarang: IAIN Walisongo Semarang.

McBeth, W. \& Volk, T.L. (2010). The national environmental literacy project: a baseline study of middle grade students in the United States. The Journal of Environmental Education, 41(1)

Melaville, A., Berg, A. C., \& Blank, M. J. (2006). Community Based Learning Engaging Students for Succes and Citizenship. https://doi.org/10.1002/TRTR.01099

National Research Council. (2009). A New Biology for the 21st Century. In A New Biology for the 21st Century. Washington, DC: The National Academies Press. https://doi.org/10.17226/12764

Perrotti, C. (2019). Review Essay: The Campus and the Neighborly Community. Michigan Journal of Community Service Learning, 25(2). https://doi.org/10.3998/mjcsloa.3239521.0025.205

Rosyada, D. (2007). Paradigma Pendidikan Demokratis: Sebuah Model Pelibatan Masyarakat dalam Penyelenggaraan Pendidikan. Jakarta: Kencana Perdana Media.

Rusmawan. (2017). Ecoliteracy Dalam Konteks Pendidikan Ips. Jurnal Sosio Didaktika: Social Science Education Journal, 4 (2)

Wickersham, C., Westerberg, C., Jones, K., \& Cress, M. (2016). Pivot Points: Direct Measures of the Content and Process of Community-based Learning. Teaching Sociology, 44(1), 17-27. https://doi.org/10.1177/0092055X15613786 
Zlotkowski, E. (1995). Does Service Learning Have a Future? Michigan Journal of Community Service Learning. 2(1), 123-133.

Undang-Undang Republik Indonesia Nomer 20 Tahun 2003 Tentang Sistem Pendidikan Nasional. http://kemenag.go.id/file/dokumen/UU2003.pdf 